\title{
Hervormde Barthiaanse Skrifbeskouing: Waarheidsbegrip
}

\begin{tabular}{|c|c|}
\hline $\begin{array}{l}\text { Author: } \\
\text { Gert J. Malan }\end{array}$ & \\
\hline $\begin{array}{l}\text { Affiliation: } \\
\text { }{ }^{1} \text { Department } \\
\text { Testament Stu } \\
\text { Theology, Uni } \\
\text { Pretoria, Sout }\end{array}$ & $\begin{array}{l}\text { f New } \\
\text { dies, Faculty of } \\
\text { versity of } \\
\text { h Africa }\end{array}$ \\
\hline $\begin{array}{l}\text { Research Proj } \\
\text { Project Leade } \\
\text { Project Numb }\end{array}$ & $\begin{array}{l}\text { ect Registration: } \\
\text { r: E. van Eck } \\
\text { er: } 2400030\end{array}$ \\
\hline $\begin{array}{l}\text { Description: } \\
\text { Dr Malan is pa } \\
\text { the research p } \\
\text { 'Socio-cultura } \\
\text { directed by Pr } \\
\text { van Eck, Depa } \\
\text { Testament Stu } \\
\text { Theology, Uni } \\
\text { Pretoria }\end{array}$ & $\begin{array}{l}\text { rticipating in } \\
\text { roject } \\
\text { I Readings', } \\
\text { of. Dr Ernest } \\
\text { rtment of New } \\
\text { dies, Faculty of } \\
\text { versity of }\end{array}$ \\
\hline $\begin{array}{l}\text { Correspondin } \\
\text { Gert Malan, } \\
\text { gertmalan@te }\end{array}$ & $\begin{array}{l}\text { g author: } \\
\text { lkomsa.net }\end{array}$ \\
\hline $\begin{array}{l}\text { Dates: } \\
\text { Received: } 11 \text { I } \\
\text { Accepted: } 10 \\
\text { Published: } 28\end{array}$ & $\begin{array}{l}\text { May } 2017 \\
\text { une } 2017 \\
\text { Sept. } 2017\end{array}$ \\
\hline $\begin{array}{l}\text { How to cite th } \\
\text { Malan, G.J., } 2 \\
\text { 'Hervormde B } \\
\text { Skrifbeskouin } \\
\text { Waarheidsbeg } \\
\text { Teologiese Stu } \\
\text { Theological St } \\
\text { a4650. https:/ } \\
\text { 10.4102/hts.v }\end{array}$ & $\begin{array}{l}\text { is article: } \\
17, \\
\text { arthiaanse } \\
\text { : } \\
\text { rip', HTS } \\
\text { dies/ } \\
\text { udies 73(1), } \\
\text { /doi.org/ } \\
73 \text { i1.4650 }\end{array}$ \\
\hline $\begin{array}{l}\text { Copyright: } \\
\text { ( 2017. The } \\
\text { Licensee: AOS } \\
\text { is licensed un } \\
\text { Creative Comr } \\
\text { Attribution Lic }\end{array}$ & $\begin{array}{l}\text { uthors. } \\
\text { IS. This work } \\
\text { ler the } \\
\text { nons } \\
\text { ense. }\end{array}$ \\
\hline Read online: & \\
\hline 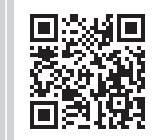 & $\begin{array}{l}\text { Scan this QR } \\
\text { code with your } \\
\text { smart phone or } \\
\text { mobile device } \\
\text { to read online. }\end{array}$ \\
\hline
\end{tabular}

The 'Hervormde' blend of Barthian view of Scripture leads to a specifically nuanced concept of biblical truth. Biblical truth is neither knowledge, dogma or faith propositions, nor historical, scientific or geographical truth. Biblical truth is a Person, sharing in dialogue with humanity regarding a relationship of God for humanity. Biblical truth is relational and metaphorical. Its imperatives are demythologisation, and ideological and cultural critique. This concept of truth is in contrast to the truth concept of most church members, because of their literal and often fundamentalist views of Scripture. In order to convey understanding of the truth concept, the 'Hervormde' view of Scripture should be discussed with them. A confession should be formulated for post-modern believers.

\section{Inleiding}

'Waarheidsbegrip' verwys in hierdie artikel na die soort waarheid wat in die Bybelse dokumente gevind word. Hoe Bybelse waarheid verstaan word is direk afhanklik van Skrifbeskouing. Hierdie artikel volg op'n voorafgaande artikel oor die Hervormde variant van Karl Barth se Skrifbeskouing en handel oor aspekte van 'n waarheidsbegrip geformuleer na aanleiding daarvan. In hierdie artikel word nie alleen verwys na teoloë aan die Pretoria Universiteit se Teologiese Fakulteit nie, maar ook ander teoloë n.a.v. hulle relevante publikasies in Hervormde Teologiese Studies. Die artikel se aanpak is nie histories en kronologies nie. ${ }^{1}$ Hervormde teoloë se insigte oor Skrifbeskouing en aspekte van waarheidsverstaan, of afleidings gegrond daarop, is geneem as rubrieke vir hierdie argument.

Dit is belangrik om daarop te let dat die waarheidsbegrip wat hier aan die orde kom, spesifiek voortvloei uit die Hervormde weergawe van Barth se Skrifbeskouing. Dit is nie algemeen geldend in die Nederduitsch Hervormde Kerk van Afrika nie, hoewel sodanige Skrifbeskouing deel was van die opleiding van predikante. Sommige Hervormde teoloë aan die fakulteit en predikante onder hulle invloed, het nie die Hervormde weergawe van Barth se Skrifbeskouing aanvaar nie, maar vasgesteek by 'n letterlike Skrifverstaan, wat 'n andersoortige waarheidsbegrip tot gevolg het. Verder verskil lidmate sonder teologiese opleiding se waarheidsbegrip ook grootliks van die onderhawige.

Wat die verloop van die artikel betref, sal die aard van die waarheidsbegrip bespreek word, gevolg deur die bespreking van imperatiewe wat daaruit voortvloei.

\section{Die waarheid is ' $n$ Persoon}

Die Barthiaanse vertrekpunt is dat dit in die Skrif as openbaring handel oor Jesus Christus as God se eie direkte en onbemiddelde spreke midde in die geskiedenis as eenmalige, beslissende gebeure (Van Zyl 1944:124). Met Christus as die spreker van God se spreke word dit duidelik dat die waarheid van huis uit ' $n$ Persoon is en nie kennis of 'n geopenbaardheid nie (Buitendag 2008:1136). Tog is dit so dat die Skrif nie direkte toegang tot God en Christus bied nie. Die neerslag van mense se veelvuldige en soms uiteenlopende geloofsverstaan in bepaalde sosio-kulturele en historiese kontekste word in die Bybel teëgekom. Om eenheid midde in die verskeidenheid van spreke oor God en verstaan van God te vind, is harmonisering nie die oplossing nie. Daarby maak die polivalensie van tekste die saak nog ingewikkelder, omdat daar nie gepraat kan word van 'die' betekenis van die teks nie (Pelser 1989a:446-447). Van Aarde bied 'n werkbare oplossing aan. Hy keer met 'n ander roete terug na Barth se vertrekpunt, naamlik Christus, deur die 'Jesus-saak' as

1.Die outeur veronderstel dat lesers vertroud is met die ter sake breë historiese agtergrond soos die oorgang vanaf die modernisme na die na-moderne denkklimaat, die politieke geskiedenis van Suid-Afrika en die Nederduitsch Hervormde Kerk van Afrika oor die afgelope 100 jaar en die ontwikkeling van eksegetiese metodes van etimologie en etiologie na histories-kritiese verstaan, strukturalisme en narratiewe leesstrategieë tot sosiaal-wetenskaplike benaderings. 
kanon agter die kanon voor te stel (Van Aarde 2012). Hierdie oplossing is werkbaar omdat histories-kritiese eksegese tot ' $n$ groot mate kon vasstel wat die waarskynlike woorde en dade van Jesus en die geloofsuitinge van sy volgelinge was, en kan sodoende die wesenlike van die Jesus-saak dekodeer op so 'n manier dat gelowiges vandag steeds aan die Jesus-saak kan deelneem (Van Aarde 2001:150). Die tradisies wat oorgelewer is en in die tekste neerslag gevind het, dui op die historiese en tradisie-aard van die kerugma. Jesus word verstaan as God se koms na die mense. Deur die tradisies hieroor ontmoet God mense steeds en leer mense God ken as God vir die mense. Dit sluit nie die Ou-Testamentiese tekste uit nie, omdat God daarin ook so aangebied word (Van Aarde 2001:148-149; 2012). Van Aarde se sienswyse hieroor gee dus 'n tree verder met die ontwikkeling van 'n waarheidsbegrip deur die relasionele aard aan te dui.

Met die vertrekpunt dat die waarheid waarvan die Skrif getuig 'n Persoon is, God vir die mense, behoort gesê te word watter soort waarheid die Skrif nie pretendeer om aan te bied nie. Die waarheid van die Skrif is nie geleë in die historiese, wetenskaplike, geografiese of enige ander vorm van akkuraatheid van die inhoud nie. Dit is dus nie historiese, geografiese, kulturele of wetenskaplike waarheid nie. Die Bybelskrywers is ook nie deur die Heilige Gees geïnspireer in die sin dat alle aspekte van wat hulle geskryf het waar is vir alle tye nie. Stellings is dus nie waar bloot omdat dit in die Bybel geskryf staan nie. Dit is nie ewige waarhede, proposisies en dogmas nie. Dit is ook nie waarheid omdat die Bybel as 'n geïnspireerdheid beskou word nie. Waarheid beteken dus nie onfeilbaarheid nie. Die waarheid van die Bybel, naamlik die spreke van God in Jesus Christus, is in feilbare en feilende mensewoorde verwoord (Van Zyl 1944:127-128).

Wanneer gesê word dat die waarheid van die Skrif 'n Persoon is, beteken dit nie dat God as objek volledig kenbaar word nie. Openbaring is tegelyk verhulling, want die spreke oor God is indirek, 'n teken van 'n teken (Buitendag 2008:1138). Daarom is daar ook nie sprake van objektiewe spreke oor God nie, omdat dit altyd persoonlik en subjektief is. Die vertrekpunt dat die waarheid 'n Persoon is, skiet dus tekort en vra om aanvulling wat die subjek-objek skema ophef. Daartoe kan die metafoor van 'n ontmoeting bydra. Die waarheid is nie slegs ' $n$ Persoon nie, maar Persoon in ontmoeting, 'n gebeure, 'n dialoog (Van Zyl in Geyser 1989:259-260).

\section{Die waarheid is ' $n$ dialogiese ontmoetingsgebeure}

Met die vertrekpunt dat die waarheid 'n Persoon is en dat dit handel oor 'spreke' waarvan die inhoud is dat God vir die mense is, kan dit nie anders as dat die waarheid die kenmerk van 'n kommunikasiegebeure sal dra nie. Dit impliseer 'n soort ontmoeting waar minstens twee partye deelneem aan 'n gesprek. Hierdie ontmoeting vind plaas wanneer God deur die kerugma tot iemand spreek. Die feilbare mensewoorde van die kerugma, of dit in die Skrif, die prediking of sakramente is, word die gebeurtenis van God se eie spreke tot mense (Van Zyl 1944:127). Hierdie ontmoetingsgebeure is geen noodwendigheid nie. Daar is dus geen noodsaak vir God se spreke tot mense nie. Dat God tot mense spreek is net genade. Maar hierdie spreke is nooit los te maak van die Skrif as Woord van God nie, maar tegelyk moet God se spreke deur feilbare mensewoorde opnuut Woord van God word vir die toehoorders daarvan. Dit is nie sonder meer so nie (Van Zyl 1944:126).

Die Bybel bevat die neerslag van menslike geloofsverstaan, wat beteken dat gelowiges bepaalde gebeure ervaar het as God se selfbetuiging aan hulle oftewel God se aanspraak op hulle (Pelser 1989a:444), aldus 'n 'ontmoeting' met God. Sodanige ontmoetings het altyd 'n datum (Van Zyl 1944:128) en derhalwe ' $n$ identifiseerbare sosio-kulturele en historiese gesitueerdheid, of dit nou in die onderskeie Bybelse dokumente is, of die kerugma wat op grond daarvan tot mense spreek. Geloofsverstaan is gegrond in die erkenning van deur God aangespreek te wees (Van Zyl 1944:130) op so 'n manier dat 'n mens God in die hart kon kyk (Buitendag 2008:1136-1137) en God sien as die Komende na mense toe, ten einde God vir mense te wees (Van Aarde 2001:148-149); God met ons (Buitendag 2008:1136). Geloofsverstaan is dus persoonlik en die spreke daaroor subjektief. Die toehoorder van God se Anrede is eksistensieel betrokke daarby en word voor die keuse gestel om persoonlike eksistensie te laat bepaal deur die 'hart' van God komende, as God pro me. Dit is geloof as positiewe deelname aan die dialoog met God en die gevolg van die kerugma (Van Aarde 2004:511). Alleen deur geloof is God se aanspraak herkenbaar, word kerugma Woord van God en kom God herkenbaar tot spreke deur Christus; word geloof antwoord op God se spreke. Tog is God se aanspraak ook konfrontasie wat disoriënteer én heroriënteer; wat versoening aanbied én bekering vereis; wat verras, oorweldig, uitdaag, ontstel, konfronteer, verbaas (Buitendag 2008:1149) en dus 'n nuwe verhouding daarstel.

Die waarheid van die Bybel is daarom nie 'n voor-diehandliggende waarheid nie. Net soos die Bybel opnuut Woord van God moet word deurdat ons die aanspraak van God op ons daarin verneem, so moet die waarheid van die Bybel opnuut God se waarheid vir ons word. Wanneer ons die Bybel lees, beskik ons dus nie oor die waarheid nie, maar hoop ons om telkens weer die openbaringswaarheid van God daarin te verneem. Sonder geloof is hierdie waarheid nie geloofwaardig nie. Die Bybelse waarheid word egter nie vir geloof, vir die Kerk, waarheid waaroor ons beskik nie, maar waarheid wat oor ons beskik en ons oortuig dat ons aan God behoort. Hierdie waarheid is dus God se genade aan ons, die inhoud sowel as die geloof wat dit as beslissende waarheid aanvaar. Hierdie waarheid is die waarheid wat die Kerk moet verkondig (Van Zyl 1944:129-132).

\section{Relasionele waarheid}

Die ontmoetingsgebeure met die waarheid kan 'n dialoog word wat' $n$ verhouding of relasie tot gevolg het, wat die Bybel geloof noem. Die waarheid is dus nie alleenlik by die objek of slegs by die subjek waarneembaar nie, maar in die relasie. Om die 
waarheid as relasie te ontbloot raak die netwerk van sosiale bindings waarby 'n persoon ingebed is. Danksy die insigte van die Kennissosiologie het dit duidelik geword dat sosiale groeperings hulle sosiale funksionering legitimeer aan die hand van 'n simboliese verstaansraamwerk. Dit kan byvoorbeeld hulle godsdiens, filosofie, verstaan van hulle herkoms of hulle politieke ideologie wees. Sonder so 'n oorkoepelende sisteem kan 'n groep nie hulle identiteit, leefwyse en voortbestaan verseker nie, omdat die denksisteem dit alles legitimeer. Daarsonder word alles sinloos en gaan die sosiale orde tot niet. Hierdieinsigte bring die gevolgtrekking dat daar vir verskillende sosio-kulturele groeperings verskillende idees kan bestaan oor wat waarheid en singewend sou wees. Hieroor het elke groep eie vooronderstellings. Eksegete en Bybelskrywers kom uit 'n verskeidenheid sodanige sosio-kulturele en teologiese groeperings (Geyser 2000:528-530), wat impliseer dat die grense van 'waarheid' nie meer duidelik omlyn is nie, maar eerder geperforeerd is. Die erkenning hiervan het tot gevolg dat die objektiewe beskouing van die waarheid verwerp word en dat beweeg word in die rigting van 'n subjektiewe verstaan, waar eksegete deelneem aan die 'produseer' van die waarheid. 'n Poging tot balans tussen die twee uiterstes word verkry wanneer die relasie tussen die pole van subjek en objek die fokuspunt word in die sogenaamde relasionele waarheidsbegrip volgens die 1981 Rapport aan die Gereformeerde Kerken van Nederland getitel 'God met ons' (Geyser 2000:530-532). Die waarheid van die Bybel is nie gelyk te stel aan die optelsom van objektiewe en subjektiewe siening van die Bybelleser nie (Geyser 1985:121). Waarheid is dus geleë in die aard van die verhouding tussen objek en subjek, wat opnuut ontdek moet word, midde in hulle eie sosio-kulturele staanplek. Waarheid is nie 'n objek, 'n ding wat voorhande is en opgeraap kan word nie. Dit is iets wat slegs met moeite aan die lig gebring kan word (Geyser 2000:531). Daarby is die waarheid van die Bybel alleen te ken binne die raamwerk van 'n geloofsverhouding met Christus (Van Aarde \& Geyser 2004:17). Dit kan omskryf word as 'ontmoeting met God in die Seun' (Van Aarde \& Geyser 2004:18), wat aandui dat die waarheid ' $n$ relasionele gebeurteniskarakter het en dinamies is. Van Zyl (in Geyser 1989:259-260) praat daarom na aanleiding van Emil Brunner oor die waarheid as ontmoeting. Wie deur die Woord in aanraking kom met die wesenlike van die openbaring, Jesus Christus, word ook geroep tot 'n persoonlike verhouding en God.

Dit is egter nie net 'n saak tussen 'n gelowige en God nie en is ook nie staties nie. Gelowiges is ingebed in 'n kultuurlinguistiese nis wat alle verstaan bepaal of beïnvloed en voortduur sodat gister se openbaring tot vandag se tradisie word en dit weer basis word vir môre se insigte. Die waarheid van die openbaring moet vasgelê word maar ook vertolk word. Sonder vaslegging vervloei dit in persoonlike opinies en sonder vertolking verstar geloof in proposisies en is dit nie meer relasie nie (Buitendag 2008:1150).

\section{Metaforiese spreke}

Menslike taal is ontoereikend om oor die Gans-Andere te praat en die relasie met gelowiges te verwoord. Tog het die ontmoetings met God wat in die Bybeltekste neerslag vind, destydse gelowiges daartoe gedring om nie te swyg nie maar na analogie van die menslike leefwêreld oor God te praat in metaforiese taal. Metaforiese taal is nogtans nie ' $n$ kragtelose taalvorm nie maar juis dinamies, want 'n metafoor vergelyk twee ongelyksoortige teenoorgesteldes met mekaar in terme van die dubbele referensie van te wees en nie te wees nie. So kom 'n kreatiewe dialektiek tot stand want metafoor herinterpreteer die werklikheid en ontsluit nuwe moontlikhede na gelang van wat in die werklikheid gevind en ontdek word. So beskou word die teenoorgesteldes nie net mekaar se teendeel nie, maar juis mekaar se identiteit (Buitendag 2008:1143).

\section{Imperatiewe van die waarheid}

Die kerk as geloofsgemeenskap is mense wat in ontmoetings met God betrokke was en die relasie met God as singewend beskou. Dit kan dus nie anders nie dat die verkondiging as fasilitering van verdere ontmoetings met God 'n wesenlike imperatief aan die kerk sal wees nie. Vervolgens word drie imperatiewe rakende die verkondiging uitgelig, waarop Hervormde teoloë klem gelê het.

\section{Ontmitologisering}

Waarheidsbegrip sluit aan by werklikheidsverstaan. Die Nuwe-Testamentiese kerugma word aangebied in mitiese begrippe wat deel vorm van 'n antieke mitologiese werklikheidsverstaan wat nie spesifiek Christelik is nie en onverstaanbaar is vir hedendaagse mense sodat die kerugma vir hulle al minder sin het (Pelser 1987:166-170). Dit sny aan by die spanning tussen die antieke drievlak-mitologiese wêreldbeeld en gepaardgaande voorwetenskaplike werklikheidsverstaan, die huidige wetenskaplike kosmologie en tegnologies-wetenskaplike werklikheidsverstaan. Hervormde teologie het veral danksy Gert Pelser (1987; 1989b; 1997) se kritiese waardering van Bultmann se ontmitologiseringsprogram al meer daarvan kennis geneem en dit het deel geword van Hervormde hermeneutiek. 'n Aantal artikels oor ontmitologisering en die verstaan van mites in HTS bevestig dit (Malan 2000; 2015; 2016a; 2016b; Van der Merwe 1987; Van Wyk 2015). Bultmann het nie soos D.F. Strauss die mitologie uit die Nuwe-Testamentiese verkondiging probeer elimineer nie, maar raakgesien dat die mite uitdrukking van menslike eksistensie is en dit probeer ontgin vir die verkondiging (Geyser 2000:534-535). ${ }^{2}$ Die mitologiese drieverdieping wêreldbeeld is deel van 'n mitiese werklikheidsverstaan wat die Bybelse verkondiging en sosiale leefwêreld van die Bybelse geloofsgemeenskappe oorspan en legitimeer (Malan 2016b). Mitologie is meer as 'n denkraamwerk. Bultmann benut begrippe uit Heidegger se eksistensiefilosofie soos Dasein, wat impliseer dat werklikheidsverstaan 'n unieke en definiërende verhouding en kohesie veronderstel tussen individue, hulle medemens en fenomene in die wêreld. Die impak wat werklikheidsverstaan as ons verhouding tot die wêreld het op ons identiteit en selfverstaan is so wesenlik dat 'n mens 2.Hierin bou hy voort op die werk van Jaspers (Malan 2015) en het hy waardering ontvang van Paul Ricoeur (Malan 2016a). 
kan sê: 'Ek is my wêreld (Malan 2016c).' Ten einde byvoorbeeld Jesus se genesings en ander wonders te verstaan, is ontmitologisering as die vertaling van die mitologiese werklikheidsverstaan in eksistensiële terme, noodsaaklik (Pelser 1987:167-174). Dit geld veral die eskatologiese aard van die Nuwe-Testamentiese kerugma, wat daaroor praat in terme van twee Hoffnungsbilder, te wete die Joodse en Hellenisties-Gnosiese verwagtings wat nie meer vir moderne wetenskaplik georiënteerde mense verstaanbaar of singewend is nie (Pelser 1989b:816-817). Net so is Bultmann se hantering van die mitologies verwoorde verkondiging van Jesus se opstanding krities-waarderend beskou. Bultmann het Jesus se opstanding beskou as uitdrukking van die betekenis van Jesus se kruisdood. Hy het dit nie beskou as die herlewing van sy dooie liggaam nie en dit daarom nie as historiese gebeure beskou nie. Hy het ook nie die opstanding gereduseer tot die ontstaan van 'n paasgeloof by die dissipels nie. Dit is met die Johannese standpunt van die opstanding as Jesus se verhoging en andersyds sy terugkeer in die ervaring van geloof waarmee Bultmann hom vereenselwig het. Sy standpunt was dat die verkondiging die enigste teologies-legitieme moontlikheid van spreke oor die opstanding is (Pelser 1997:473).

Die bydrae van ontmitologisering tot die waarheidsbegrip in Hervormde teologie is dat die Bybelse waarheid al meer verstaan word as eksistensiële waarheid. Die antieke mitologiese werklikheidsverstaan word nie weggesny nie maar geherinterpreteer in eksistensiële terme wat ons selfverstaan en Dasein vorm. Verkondiging en geloof fokus daarom op die eksistensiële betekenis van byvoorbeeld die heilsgebeure en dit word so 'n wesenlike deel van ons Dasein, eerder as die vereiste aanvaarding daarvan as objektief aanwysbare historiese gebeure wat van geloof 'n sacrificium intellectus maak en daarmee tot 'n werk verklaar word na die Lutherse verstaan daarvan.

\section{Ideologiekritiek}

Waarheidsbegrip staan vanweë die Hervormde beskouing van die Bybel as Woord van God teenoor ideologie. Hierdie onderskeid word nie net vanuit die Bybel gemaak nie, maar is binne die Bybel uitgewys. So verwys prof. Geyser (1961) in 'n huldeblyk aan prof. Gemser na aanleiding van 'n artikel van Gemser in die Almanak van 1940 waar hy gehandel het oor nasionalisme en universalisme in die prediking van die $\mathrm{Ou}$ Testament. Geyser verwys na profete wat vervolg is omdat hulle teenoor die nasionale teologie God se spreke laat hoor het en noem dat navolgers van Jesus se lot dieselfde sal wees as hulle Meester s'n, '... wat gesterf het onder die hande van nasionalisme wat uitgeswel het tot 'n ideologie' (Geyser 1961:300). Geyser stel konsekwent die Bybel as Woord van God teenoor politieke ideologieë soos nasionalisme, nazisme en kommunisme. ${ }^{3}$ Hy wys op die 'geraffineerdheid' van ideologie wat die Woord van God uitdaag binne die domein van die Woord self, naamlik die Christelike kerk, ten einde

3.Geyser praat in Barthiaanse terme oor die Bybel as Woord van God in'n tydvak toe Apartheid as ideologie vanuit die Bybel deur die Hervormde teologie geregverdig was. Sy grondige dialektiese redenasie het hom duur te staan gekom en hy het persona non grata in die Hervormde kerk geword (Van Aarde et al. 2014). die Woord te verdring. Hy stel die vernietigende krag van ideologie teenoor die Woord as 'innerlike sin van dinge en manifesteerder van die waarheid' (Geyser 1961:304-305). Die singewende vleesgeworde Woord waarin God sy essensie bekendgemaak het, ' ... is liefde, en het onbeperkte, ongekwalifiseerde liefde gepreek, geleef en volmaakte liefde gesterf en opgestaan' en vra van gelowiges soortgelyke selfverloëning teenoor ideologiese strewe na selfbehoud (Geyser 1961:306).

Na Albert Geyser se skuldigbevinding aan dwaalleer deur die destydse moderamen op 8 Mei 1962, bedank prof. Adrianus van Selms as professor in Ou Testament aan die Pretoria Universiteit uit protes daarteen, omdat sy gewete hom verbied om toe te laat dat enige mens aan hom voorskryf wat die Woord van God sê (Dreyer 2016). Van Selms redeneer dus kenmerkend Hervormd: die Woord van God, wat telkens weer vry moet wees om Woord van God te word, staan verhewe bo enige menslike vasstelling van wat die Woord moet sê. Dit wys ook dat die Hervormde Skrifbeskouing nie net toegepas word in die eksegese, prediking of dosering van die teologie nie, maar geleef behoort te word in die praktyk en spanningsveld van die gelowiges se lewe. In hierdie verband stel Loader as vertrekpunt die tese dat die Bybel die gevolg is van Israel se erkenning van mislukking (skuldbelydenis) en hou Israel se eerlike introspeksie as model voor die Hervormde kerk wat deur eksistensiële worsteling erken het dat die teologiese regverdiging van Apartheid verkeerd was en huidige krisisse, soos die gevolglike kerkskeuring, moet verwerk (Loader 2014).

\section{Kultuurkritiek}

Soos wat die dialektiese Skrifbeskouing hom afgrens teen ideologie, behoort dit krities te staan teenoor kultuur, spesifiek omdat die waarheid van die kerugma aanspraak maak op onvoorwaardelike diens aan God. Dialektiese denke sien kultuur as ' $n$ moeilike definieerbare dimensie van menswees wat op abstrakte vlak funksioneer en bepalend is vir mense se denke, houdings, emosies en waardes, lewenspatrone en geloof. Dit tree na vore by mense se interaksie binne die kollektiewe struktuur van ekonomie, politiek, familie en godsdiens. Kultuur is vir menslike bestaan 'n onontkombare en determinerende faktor (Van Aarde 1996:834-835). Hierdie determinasie is nie net aan die werk op empiriese vlak nie. Dit is ook aanwesig as deel van die simboliese universum wat die sosiale leefwêreld oorspan en legitimeer. Dit kan teologies beskou word as 'n skeppingsordening in terme waarvan mense leef en kan verstaan word as natuurgegewe imperatief. 'n Kultuurkritiese benadering in die teologie vra of sinvolle lewe afhanklik is van hierdie soort skeppingsordening asof dit ' $n$ Godgegewe imperatief is. Kultuurkritiek antwoord negatief op hierdie vraag en soek na 'n alternatiewe wysheid eerder as die beskouing wat kultuur Bybels wil legitimeer (Van Aarde 2005:684-687).

Kultuurkritiek is die kritiese studie van kultuur. Dit opponeer die positiwistiese subjek-objekskema wat kennis beskou as 'n eenrigting proses van objek na subjek en verkies om dit te 
verstaan as dialektiese en funksionele interaksie tussen objek en subjek (Van Aarde 1996:835). Dit is anti-fondamentalisties aangesien die gedagte verwerp word dat alle kennis gebou is op ' $n$ vaste fondament, maar beskou kennis en sekerheid daarvan eerder as verweef in die struktuur van kennis. Die doel van kultuurkritiek is om godsdiens te ontmasker wanneer dit neerkom op'n akulturalisering van tradisies. Kultuurkritiek word deurgevoer deur alle tradisies te konfronteer in die soeke na tekens van transendensie wat daarin neerslag gevind het. ${ }^{4}$ Dit word aangepak met empiriese metodes, veral die metodes van moderne historiese ondersoek en is vry van dogmatiese $a$ priori's soos by die neo-ortodoksie. Die gesindheid is een van geduldige induksie en 'n openheid jeens die volle spektrum van menslike ervaring wat vir historiese studie toeganklik is (Van Aarde 2005:687-692).

Indien die kerk se selfverstaan op Jesus se alternatiewe wysheid van die koninkryk van God gebaseer is, kan die kerk nie anders as om kultuur-krities te wees nie sodat die singewende van die koninkryk verkondig word en onvoorwaardelik aanvaar en gedien kan word. Jesus se verkondiging van die koninkryk van God het teenoor die gangbare wysheid stelling ingeneem. Daardie wysheid was kultureel beskou as 'n skeppingsordening. Wysheid het beteken dat mense hulle onderwerp aan die konvensionele wysheid wat as God se orde voorgehou is. Daarvolgens het alles en almal 'n plek, tyd en rol, regte en voorregte gehad, wat bepaal is deur die stand van die familie waarin iemand gebore is, die beginsels van eer en skande en die reinheidsvoorskrifte wat bepaalde grade van reinheid en onreinheid aangedui het. Die wortels van die gangbare wysheid is terug te vind in die vergeldingsleer en in Jesus se tyd was die Fariseërs by uitstek verteenwoordigers hiervan (Van Aarde 1996:845-846). Hierteenoor verkondig Jesus die koninkryk van God, wat Markus 'evangelie' noem, en wat Paulus beskryf in terme van genade. Jesus definieer die koninkryk metafories as 'n nie-hiërargiese denkbeeldige huishouding waar almal in die familie gelyke toegang het tot die Vader, waar die Vader sorg vir hulle wat hulle armoede voor God erken en waar hulle ook na mekaar omsien as mekaar se fiktiewe broers en susters soos die Vader van hulle verwag. Sy konsekwente en vreeslose volharding om die koninkryk te verkondig het Jesus in konflik met die tempel ideologie en tempel-elite gebring en uitgeloop op sy kruisiging. Paulus beskou hierdie verkondiging as die manier hoe mense met God versoen word. Vir hom was sterwe met Christus om saam met Christus te leef, maar dan bevry van die mag van sonde. Die kerk se kultuurkritiek sal daarom soteriologies bepaald wees, maar weerstand daarteen sal dit oneffektief maak, tensy die soteriologiese aspekte getranskodeer word. Dit is 'n pad van transformasie wat verby konvensionele en godsdienstige wysheid beweeg na 'n verhouding met God; van 'n angsvolle bestaan na 'n lewe van vrede en vertroue. Dit is ' $n$ lewe vanuit 'n ander soort werklikheid as die gewoon kulturele en kan met die metafoor van verlossing beskryf word. Die aktualisering van die koninkryk was die geboorte van die kerk, wat van die begin af bestaan het in die spanningsveld van in die wêreld, maar nie van die wêreld te wees nie. Die Konstantynse era het gewys dat hierdie spanning prysgegee kan word wanneer die kerk en politieke magte in 'n een tot een verhouding met mekaar staan. Indien die kerk getrou aan Jesus se verkondiging van die koninkryk wil diensbaar wees, is volgehoue kultuurkritiek noodsaaklik en moet die kerk as kontra-kultuur funksioneer waar gelowiges onvoorwaardelik kan glo en dien (Van Aarde 2005:698-705).

\section{Ten slotte}

Hoe die meeste lidmate die Bybel beskou en met die waarheid daarvan omgaan, verskil tot 'n groot mate met die siening van teoloë. Die Bybel word oor die algemeen beskou as (vgl. Pelser 1989a:448-449):

- gelyk aan die Woord van God

- meganies gesagvol in al sy dele

- bevattende ewige en onveranderlike waarhede

- meganies geïnspireer

- onfeilbaar in al sy dele

- 'n getroue weergawe van die werklikheid

- 'n eenheid

- toepasbaar in elke situasie

- 'n magiese voorwerp vir sommige.

Daar is waarskynlik lidmate by wie die kloof tussen teologiese en leke Skrifbeskouing vernou het. Die onus rus op predikante om lidmate te begelei om hierdie kloof te oorbrug. Die kloof sluit ook die ravyn in wat oopgaap tussen hedendaagse Bybellesers en die sosio-kulturele en historiese kontekste van die Bybelse geskrifte. Om hierdie ravyn oor te steek verg moed, maar die beloning is telkens waardevolle insigte wat tot dieper geloof en selfverstaan lei (Malan 2010).

Die toekoms kan positief tegemoet gegaan word mits die dialektiek nie prysgegee word nie, aangesien dit die einde van die Christendom kan beteken (Van Aarde 1995:26). Met haar dialektiese Skrifbeskouing kan die Hervormde teologie ook in die toekoms 'n aansienlike bydrae lewer.

Dit is veral so omdat die postmoderne tydvak waarin ons leef en wat steeds voor ons uitstrek, nie as bedreiging gesien word nie, maar as uitdaging. Van Aarde sien dit as 'n geleentheid om juis ons Skrifbeskouing te verruim en daaroor te herbesin. Postmoderne mense weet dat die drievlakkige wêreldbeeld sowel as die 'wetenskaplike sekerheid' van die moderne en liberale teologie verbygegaan het. Die kwantumfisika het aangedui dat niks meer as eksak beskou kan word nie, ook nie die natuur nie. Tog raak postmoderne mense al meer bewus van die goddelike misterie van menswees, maar is onseker oor hoe om dit te verwoord of te legitimeer. Sommige neem afskeid van die kerk as instituut en sosiale konvensie, omdat dit deur magsmisbruik en eie belange gekontamineer is. Ander doen dit net gedeeltelik deur die waardes teenwoordig in teologieë en konvensies van onaanvaarbare waardes te probeer suiwer en deurlopend met alternatiewe waardes te vervang (Van Aarde 2004:515-516). Die uitdaging vir die teologie is om ook postmoderne lidmate 
te begelei om hulle geloof tog te kan verwoord. So 'n belydenis bied Van Aarde (2004) aan met verwysing na Gerd Theissen se omdigting van Ps 104:

God ry op die wind se vlerke, slaap in die klip, droom in die blom, staan op die wildsbok, gesels met vrouens en mans, kinders en bejaardes, swart en wit - en die Bybel vertel my hiervan. Ongeag die voorkeure van mense of groepe, leef ons coram Deo. Dit doen ons, geleerd of ongeleerd, vanuit geloof en vergifnis. Só 'n gelowige is by God soos 'n kind, laggende en huilend. Só 'n lewensbestaan is inderdaad deurdring met Gees en Skrif - ' $n$ bestaan soos ' $n$ boom wat by die rivier geplant is (Jer 17:7-8), waarvan die wortels self diep in die siel van die aarde na die water toe groei en as die droogte kom, bly dit vrugte dra en die lower bly immergroen asof dit nie-bladwisselend is. So ' $n$ mens, in die metaforiese taal vanuit die Bybel, is iemand wat soos 'n dissipel onder die vyeboom sit (Joh 1:48-49) in die verwagting om sy of haar rabbi te vind en hom gevind het in die persoon van Jesus van Nasaret, gesig van God, seun van God. (bl. 516)

Die Kerk se Skrifbeskouing behoort met lidmate bespreek te word sodat hulle gemotiveer word om die Bybel daarvolgens te verstaan. Omdat lidmate die Bybel prekrities $^{5}$ gebruik, bestaan daar die verleiding tot biblisisme en fundamentalisme (Van Eck 2008:1155-1185). Dit lei tot 'n boekgodsdiens wat geloof in God kan verplaas na geloof in die Bybel. Geloof word dan die vrug van die leer oor die goddelike geïnspireerdheid van die Skrif. So 'n boekgodsdiens lyk prysenswaardig, maar is volgens Paulus ' $n$ futiele strewe na eiegeregtigheid (Rom 10:2-4). Lidmate behoort begelei te word om die Bybel te bestudeer ter wille van die kerugma (verkondiging van Christus) en outentieke geloof. Die kerugma is die middel waardeur die versoening aangekondig word en dus waardeur die redding geskied tot ' $n$ radikale andersheid as die lewe sonder God. Die Skrif is egter nie op sigself kerugma nie en daarom ook nie die grond van die geloof in Christus nie. Geloof is eerder die grond van die gesag van die Skrif. Geloof is die gevolg van die kerugma en staan los van hoe die dokumente van die Skrif tot stand gekom het. Inspirasie behoort daarom nie beperk te word tot inspirasie van die Skrif nie, maar moet verstaan word as die totaal van die Gees se handelinge met gelowiges, wat uitleg, verkondiging, geloof en etiese lewe insluit (Van Aarde 2004:509-511).

\section{Erkenning \\ Mededingende belange}

Die outeur verklaar dat sy geen finansiële of persoonlike verbintenis het met enige party wat haar nadelig kon beïnvloed het in die skryf van hierdie artikel nie.

\section{Literatuurverwysings}

Buitendag, J., 2008, '“God met ons" - Gelowig nagedink oor die Skrif', HTS Teologiese Studies/Theological Studies 64(3), 1131-1154. https://doi.org/10.4102/hts.v64i3.67

Dreyer, W., 2016, 'Heretic or rebel? The heresy trial of Albert Geyser', HTS Teologiese Studies/Theological Studies 72(4), a3745. https://doi.org/10.4102/hts.v72i4.3745

5. Byvoorbeeld deur in binnekamer meditasie of psigologiese handhawing van die subjektiewe self die Bybel as 'n soort magiese geskrif te gebruik.
Geyser, A.S., 1961, 'Logos en ideologia. Woord en skynwoord', HTS Teologiese Studies 16(4), 300-307. https://doi.org/10.4102/hts.v16i4.3817

Geyser, P.A., 1985, 'Die relasionele waarheidsbegrip en die Christelike lewe: Die sinodale rapport van die GKN', HTS Teologiese Studies/Theological Studies 41(1), 119-129.

Geyser, P.A., 1989, 'Prof dr F J van Zyl se Skrifbeskouing', HTS Teologiese Studies/ Theological Studies 45(2), 253-262. https://doi.org/10.4102/hts.v45i2.2254

Geyser, P.A., 2000, 'Hermeneutiese uitgangspunte in historiese-Jesus navorsing, Deel 1: Sosiaal-wetenskaplike vooronderstellings', HTS Teologiese Studies/Theological Studies 56(2\&3), 527-548. https://doi.org/10.4102/hts.v56i2/3.1752

Loader, J.A., 2014, 'Understanding of failure and failure of understanding: Aspects of failure in the Old Testament', HTS Teologiese Studies/Theological Studies 70(1) Art. \#2657, 1-11. https://doi.org/10.4102/hts.v70i1.2657

Malan, G.J., 2000, 'Bultmann se ontmitologiseringsprogram herwaardeer', HTS Teologiese Studies/Theological Studies 56(4), 1107-1118. https://doi. org/10.4102/hts.v56i4.1809

Malan, G.J., 2010, 'Can the chasms be bridged? Different approaches to Bible reading', HTS Teologiese Studies/Theological Studies 66(1), Art. \#404, 1-10. https://doi. org/10.4102/hts.v66i1.404

Malan, G.J., 2015, 'Die Nuwe Testament en mitologie: Die probleem van die ontmitologisering van die Nuwe-Testamentiese verkondiging. Bultmann se 1941-opstel weer bekyk', HTS Teologiese Studies/Theological Studies 71(3), Art. \#2757, 1-8. https://doi.org/10.4102/hts.v71i3.2757

Malan, G.J., 2016a, 'Ricoeur on myth and demythologising', HTS Teologiese Studies/ Theological Studies 72(4), a2998. https://doi.org/10.4102/hts.v72i4.2998

Malan, G.J., 2016b, 'Combining Ricoeur and Bultmann on myth and demythologising', HTS Teologiese Studies/Theological Studies 72(3), a3216. https://doi.org/10.4102/ hts.v72i3.3216

Malan G.J., 2016c, 'Mythology, Weltanschauung, symbolic universe and states of consciousness', HTS Teologiese Studies/Theological Studies 72(1), a3243. https:// doi.org/10.4102/hts.v72i1.3243

Malan, G.J., 2016d, 'Myth as metaphor', HTS Teologiese Studies/Theological Studies 72(4), a3260. https://doi.org/10.4102/hts.v72i4.3260

Pelser, G.M.M., 1987, 'Die ontmitologiseringsprogram van Rudolf Bultmann', HTS Teologiese Studies/Theological Studies 43(1 \& 2), 162-191.

Pelser, G.M.M., 1989a, 'Die Bybel aan die universiteit en in die kerk', HTS Teologiese Studies/Theological Studies 45(2), 442-450. https://doi.org/10.4102/hts. v45i2.2287

Pelser, G.M.M., 1989b, 'Rudolf Bultmann se ontmitologisering van die NuweTestamenties eskatologie', HTS Teologiese Studies/Theological Studies 45(4), 815842. https://doi.org/10.4102/hts.v45i4.2332

Pelser, G.M.M., 1997, 'Rudolf Bultmann oor die opstanding van Jesus', HTS Teologiese Studies/Theological Studies 53(3), 455-475. https://doi.org/10.4102/hts. v53i3.1655

Van Aarde, A.G., 1994, 'Kultuurimperialisme as hermeneutiese dilemma. Eerstewereldse en Derde-wereldse perspektiewe op die Seun van God', HTS Teologiese Studies/THeological Studies 50(1 \& 2), 345-367. https://doi.org/10.4102/hts. v50i1/2.2560

Van Aarde, A.G., 1995, 'Kerk en teologie op pad na die derde millennium: 'n paradigmaskuif van middelmatige aard', HTS Teologiese Studies/Theological Studies 51(1), 39-64.

Van Aarde, A.G., 1996, 'Kultuurkritiek, die eerste-eeuse kulturele wysheid en die alternatiewe visie van Jesus van Nasaret', HTS Teologiese Studies/Theological Studies 52(4), 833-849. https://doi.org/10.4102/hts.v52i4.1572

Van Aarde, A.G., 2001, 'The "cause of Jesus" (Sache Jesu) as the canon behind the canon', HTS Teologiese Studies/HTS Theological Studies 57(1 \& 2), 148-171.

Van Aarde, A.G., 2004, 'Skrifbeskouing in die lig van Postmoderniteit', HTS Teologiese Studies/Theological Studies 60(1 \& 2), 503-532. https://doi.org/10.4102/hts. v60i1/2.502

Van Aarde, A.G., 2005, 'Cultural criticism as an imperative for Christians', HTS Teologiese Studies/Theological Studies 61(3), 683-708. https://doi.org/10.4102/ hts.v61i3.459

Van Aarde, A.G., 2012, 'The use and origin of the (old and) New Testament as Christianity's canon', HTS Teologiese Studies/Theological Studies 68(1), Art. \#1262, 1-8. https://doi.org/10.4102/hts.v68i1.1262

Van Aarde, A.G., De Villiers, P.G.R. \& Buitendag, J., 2014, 'The forgotten struggle of Albert Geyser against racism and apartheid', HTS Teologiese Studies/Theological Studies 70(1), Art. \#2820, 1-10. https://doi.org/10.4102/hts.v70i1.2820

Van Aarde, A.G. \& Geyser, P.A., 2004, 'Om nie te dink bo "wat in die Skrif geskrywe staan nie" - konsistensie en ontwikkeling in die teologie van Piet Geyser', HTS Teologiese Studies/HTS Theological Studies 60(1 \& 2), 7-28. https://doi. org/10.4102/hts.v60i1/2.501

Van der Merwe, P.J., 1987, 'Die wonder en wondervertelling gesien teen die agtergrond van mite en ontmitologisering', HTS Teologiese Studies/Theological Studies 43(1 \& 2), 192-204.

Van Eck, E., 2008, Een teks - Meerdere betekenisse: Hoe lees ons die Bybel?, HTS Teologiese Studies/Theological Studies 64(3), 1155-1185. https://doi. org/10.4102/hts.v64i3.82

Van Wyk, G.M.J., 2015, 'Rudolf Bultmann - Evangelie en geloof', HTS Teologiese Studies/Theological Studies 71(3), Art. \#3039, 1-9. https://doi.org/10.4102/hts. v71i3.3039

Van Zyl, F.J., 1944, 'Die Skrifbeskouing van Karl Barth', HTS Teologiese Studies/ Theological Studies 1(3), 124-135. https://doi.org/10.4102/hts.v1i3.3320 